\title{
SunLine Tests HHICE Bus in Desert Climate
}

SUNLINE TRANSIT AGENCY provides public transit and community services to California's Coachella Valley. Headquartered in Thousand Palms, California, SunLine's service area encompasses more than 1,100 square miles and includes nine member cities, as well as Riverside County. SunLine has more than 10 years experience with alternative fuels for bus operations. In 1994, it replaced its entire fleet with compressed natural gas $(\mathrm{CNG})$ buses. In addition to $\mathrm{CNG}$, the agency has experimented with many advanced technologies designed to reduce or eliminate emissions. These technologies include buses that run on a blend of hydrogen and $\mathrm{CNG}$, battery electric power, and fuel cells.

SunLine has become a prime location for testing advanced technology buses. Much of the experience gained with gaseous fuels, such as CNG, carries over to hydrogen. SunLine has had hydrogen infrastructure in place since early 2000 and was one of the first transit agencies to test fuel cell buses. In addition, SunLine's maintenance staff is proficient in troubleshooting problems with prototype technologies. This experience has proved invaluable in helping manufacturers develop and optimize technologies for transit applications.

IN DECEMBER 2004, SUNLINE BECAME the first transit agency to operate a hybrid hydrogen

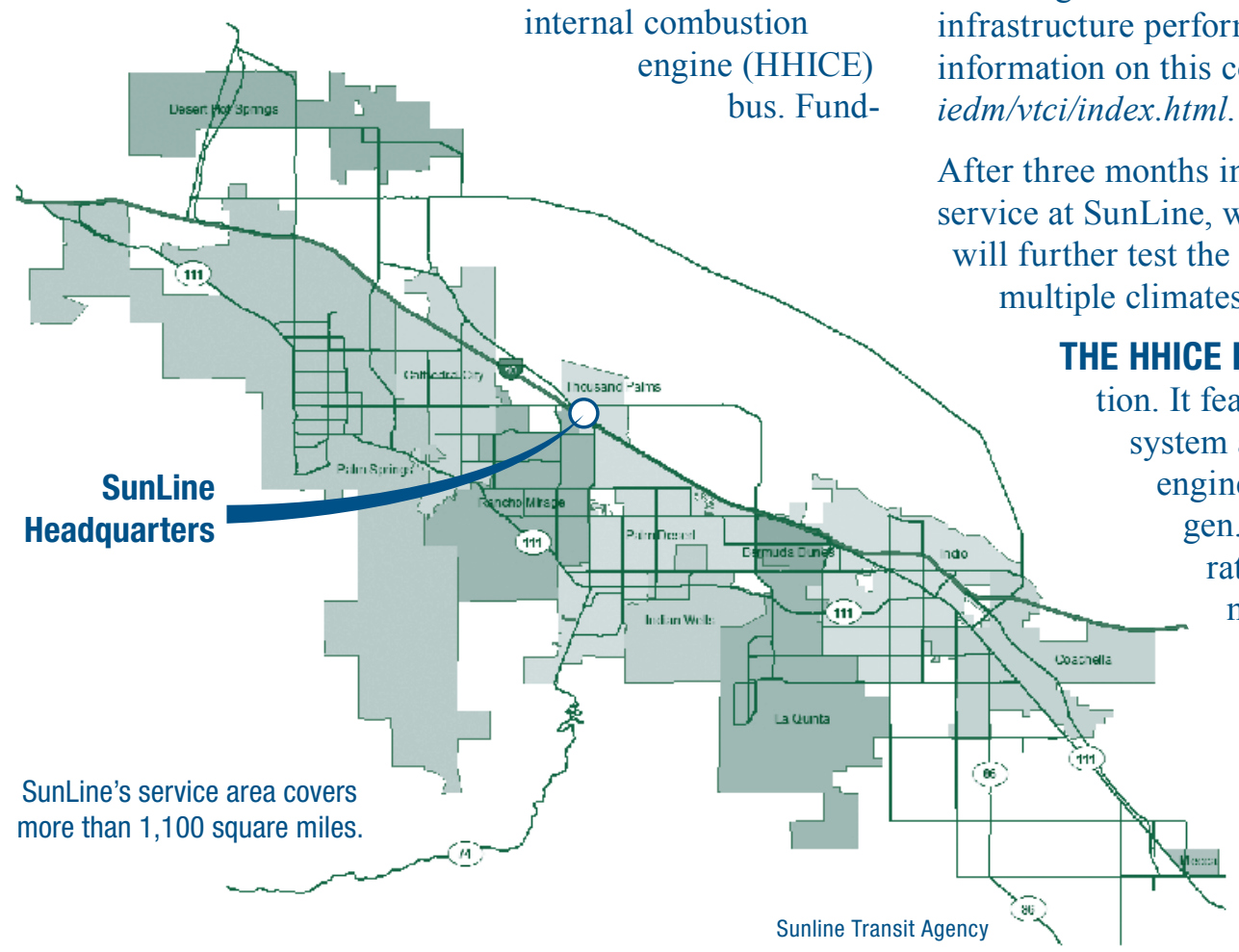

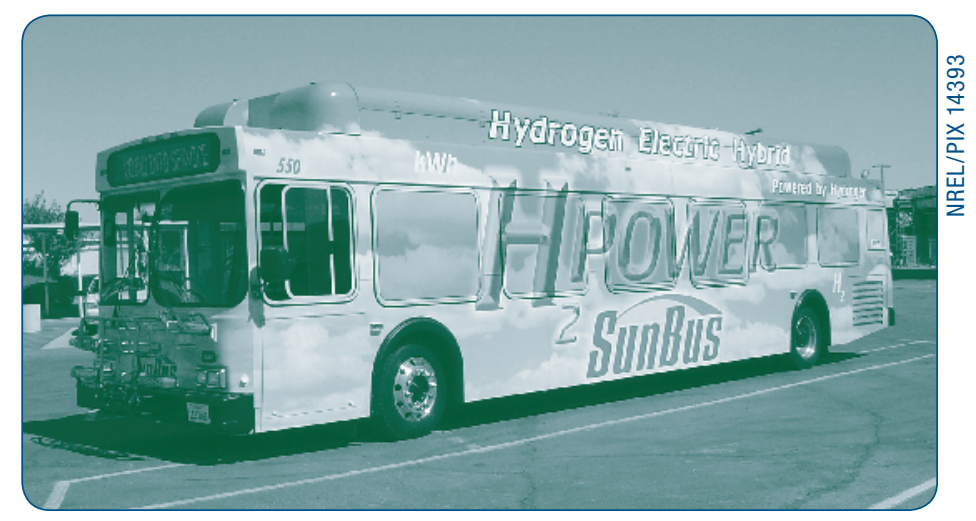

The HHICE bus features an ISE ThunderVolt hybrid drive system and a Ford Motor Company Triton V10 engine optimized to run on hydrogen.

ed as part of an international collaboration, the HHICE bus spent several weeks in SunLine revenue service in early 2005 before being sent to Manitoba, Canada, for cold-weather testing in the City of Winnipeg Transit fleet.

With temperatures dipping as low as $-27^{\circ} \mathrm{C}\left(-16^{\circ} \mathrm{F}\right)$, the HHICE bus was operated during Winnipeg's coldest months. It performed well-accumulating over 300 miles and carrying more than 1,000 passengers. The test results offer valuable insight on how the hydrogen bus and its supporting infrastructure perform in harsh winter conditions. For more information on this cold weather trial, visit www.gov.mb.cal

After three months in Canada, the HHICE bus is back in service at SunLine, where the hot, dry desert climate further test the performance of hydrogen buses in THE HHICE BUS WAS DEVELOPED by ISE Corpora. It features ISE's ThunderVolt hybrid drive ystem and Ford Motor Company's Triton V10 ngine, which is optimized to run on hydrogen. ISE's hybrid system is a series configuration, meaning that the powerplant is not mechanically coupled to the drive axle. The powerplant and energy storage system work together to provide electricity to two electric drive motors that are connected to the driveline through a combining gearbox. 


\section{SUNLINE HHICE BUS FACTS}

\begin{tabular}{|l|l|}
\hline Bus Chassis/Model & New Flyer/TB-40HICE \\
\hline Model Year & 2005 \\
\hline Length/Width/Height & $40 \mathrm{ft} / 102 \mathrm{in} / 137 \mathrm{in}$ \\
\hline GVWR & $40,000 \mathrm{lb}$ \\
\hline Seats & 39 \\
\hline Service & Revenue service \\
\hline Drive System & ISE Thundervolt Hybrid Drive System \\
\hline Powerplant & $\begin{array}{l}\text { Ford 6.8 liter V10 hydrogen internal } \\
\text { combustion engine, 190 hp }\end{array}$ \\
\hline Propulsion Motor & $\begin{array}{l}\text { Two Siemens AC induction motors, } \\
85 \text { kW each (170 kW total) }\end{array}$ \\
\hline Energy Storage & $\begin{array}{l}\text { Maxwell ultracapacitors, two packs, } \\
\text { maximum total energy stored: 0.6 kWh }\end{array}$ \\
\hline Accessories & Electrically driven \\
\hline Fuel & Gaseous hydrogen, 58 kg at 5,000 psi \\
\hline Hydrogen Storage & $\begin{array}{l}\text { Eight on-board, type III tanks by } \\
\text { Structural Composites Industries }\end{array}$ \\
\hline
\end{tabular}

The hybrid system is capable of regenerative braking, a process that captures the energy typically expended during braking and uses it to recharge the energy storage system. Each component of the propulsion system is carefully controlled through an ISE-developed operating system. ISE designed the system to be flexible, allowing for a variety of powerplants and energy storage options.

Using hydrogen in a well-established engine technology is a potential pathway for transitioning to a hydrogen society. Hydrogen-fueled internal combustion engines (ICEs) such as the engine in the HHICE bus, will help build demand and support for hydrogen infrastructure while fuel cell technology is being perfected. The HHICE bus can be a good candidate for transit agencies because fleet mechanics are familiar with the workings of combustion engines. This innate knowledge, therefore, frees up maintenance workers to focus on the nuances of using a new gaseous fuel.

\section{Project Participants}

The HHICE bus in demonstration at SunLine was developed through an international partnership, which included funding and support from the following U.S. and Canadian organizations.

- Partners: U.S. Federal Transit Administration (FTA), California Energy Commission, South Coast Air Quality Management District (SCAQMD); Natural Resources Canada; Province of Manitoba, Manitoba Energy Science, and Technology (MEST); WestStart/CALSTART

- Fleets: SunLine, City of Winnipeg Transit, Chula Vista Transit

- Manufacturers: ISE Corporation (hybrid system and integration), Ford (engine), New Flyer (bus chassis)

Hydrogen ICEs also have the potential for near-zero emissions. Because the fuel contains no carbon, the engine does not produce carbon dioxide or any other carbon compounds. The only undesirable emission is oxides of nitrogen $\left(\mathrm{NO}_{\mathrm{x}}\right)$. However, operating at ultra-lean conditions keeps the combustion temperature low enough to nearly eliminate $\mathrm{NO}_{\mathrm{x}}$ without using any aftertreatment device.

SUNLINE IS CURRENTLY COLLABORATING with the U.S. Department of Energy's (DOE) Hydrogen, Fuel Cells \& Infrastructure Technologies (HFCIT) Program on the evaluation of the HHICE bus. The agency will continue to run the bus in revenue service. DOE's National Renewable Energy Laboratory (NREL) will collect and analyze performance and operations data on the bus for at least one year.

This evaluation is one of several DOE projects that support the research and development of highly efficient, low- or zero-emission systems that will reduce our dependence on imported petroleum. The results are important in understanding the state of the technology and the work that still needs to be done. Information gathered during the demonstration will help researchers assess the status of the technology and aid fleets in making informed purchase decisions. Results will also be fed back into the research and development process to focus future resources, as appropriate.

\section{Contacts}

Sunline Transit Agancy
Tommy Edwards

760-343-3456, ext. 312

tedwards@sunline.org

National Renewable Energy Laboratory

Leslie Eudy

Senior Project Leader

303-275-4412

leslie_eudy@nrel.gov

Produced by the

National Renewable Energy Laboratory (NREL)

NREL is a U.S. Department of Energy National Laboratory Operated by Midwest Research Institute $\bullet$ Battelle

\section{Web Sites}

SunLine: www.sunline.org

ISE: www.isecorp.com

Ford: wWw.ford.com

FTA: www.fta.dot.gov

SCAQMD Technology Advancement Office: www.aqmd.gov/tao/about.html

Province of Manitoba, MEST:

www.gov.mb.ca/est/energy/

DOE: www.eere.energy.gov/hydrogenandfuelcells

NREL: www.nrel.gov/hydrogen/proj_tech validation.html
For more information contact:

EERE Information Center

1-877-EERE-INF (1-877-337-3463)

www.eere.energy.gov

A Strong Energy Portfolio for a Strong America

Energy efficiency and clean, renewable energy will mean a stronger economy, a cleaner environment, and greater energy independence for America. Working with a wide array of state, community, industry, and university partners, the U.S. Department of Energy's Office of Energy Efficiency and Renewable Energy invests in a diverse portfolio of energy technologies.

\section{DOE/G0-102006-2333 - 0ctober 2006}

Printed with a renewable-source ink on paper containing at least

$50 \%$ wastepaper, including $10 \%$ postconsumer waste. 